IZA DP No. 1109

\title{
The Gender Earnings Gap in Britain
}

Karen Mumford

Peter N. Smith

April 2004 


\title{
The Gender Earnings Gap in Britain
}

\author{
Karen Mumford \\ University of York \\ and IZA Bonn \\ Peter N. Smith \\ University of York
}

\section{Discussion Paper No. 1109 \\ April 2004}

\author{
IZA \\ P.O. Box 7240 \\ 53072 Bonn \\ Germany \\ Phone: +49-228-3894-0 \\ Fax: +49-228-3894-180 \\ Email: iza@iza.org
}

\begin{abstract}
Any opinions expressed here are those of the author(s) and not those of the institute. Research disseminated by IZA may include views on policy, but the institute itself takes no institutional policy positions.

The Institute for the Study of Labor (IZA) in Bonn is a local and virtual international research center and a place of communication between science, politics and business. IZA is an independent nonprofit company supported by Deutsche Post World Net. The center is associated with the University of Bonn and offers a stimulating research environment through its research networks, research support, and visitors and doctoral programs. IZA engages in (i) original and internationally competitive research in all fields of labor economics, (ii) development of policy concepts, and (iii) dissemination of research
\end{abstract} results and concepts to the interested public.

IZA Discussion Papers often represent preliminary work and are circulated to encourage discussion. Citation of such a paper should account for its provisional character. A revised version may be available on the IZA website (www.iza.org) or directly from the author. 
IZA Discussion Paper No. 1109

April 2004

\section{ABSTRACT}

\section{The Gender Earnings Gap in Britain*}

The earnings gap between male and female employees is substantial and persistent. Using new data for Britain, this paper shows that an important contribution to this gap is made by the workplace in which the employee works. Evidence for workplace and occupational segregation as partial explanations of the earnings gap is presented. Having allowed also for individual worker characteristics there remains a substantial within-workplace and withinoccupation gender earnings gap. The contribution of these factors, as well as the earnings gap itself, differ significantly across sectors of the labour market. The relative unimportance of occupational segregation and the large remaining gender earnings gap suggest that stronger enforcement of Equal Pay legislation is likely to be the most appropriate policy response.

JEL Classification: J3, J7

Keywords: gender earnings, wage-gap, fixed-effects, segregation

Corresponding author:

Karen Mumford

Department of Economics and Related Studies

University of York

Heslington

York, YO10 5DD

United Kingdom

Email: kam9@york.ac.uk

\footnotetext{
* We thank the WERS98 sponsors - the Department of Trade and Industry, the Economic and Social Research Council, the Advisory, Conciliation and Arbitration Service and the Policy Studies Institute for allowing access to the data. They are not responsible for any of the findings or claims made in the paper. Mumford is also grateful for financial support from the Leverhulme Foundation.
} 


\section{Introduction}

The literature on gender wage inequality is well established (see surveys by Altonji and Blank, 1999; Weichselbaumer and Winter-Ebman, 2003). Discussion of recent results for Britain is provided in a range of papers including Joshi and Paci (1998), Swaffield (2003), and Manning and Robinson (2004). Whilst there is dispersion in the findings of these studies, it is generally concluded that a substantial and persistent earnings gap exists between male and female employees.

Time series studies for Britain reveal a fall in the gender earnings gap correlated with the introduction of the first Equal Pay Act in 1970. Harkness (1996) reports a gender earnings gap of 40\% for $1973 ; 27 \%$ in 1983; and 22\% in 1992. This decline in the earnings gap in Britain has been dramatic and substantially larger than those experienced in the US (Blau and Kahn, 1997). Nevertheless, Britain's rate of change has lagged behind many of her European contemporaries (Wilborn, 1991). Furthermore, the earnings gap in Britain has shown little change over the 1990s.

The gap is commonly explained by a component due to differences in individual characteristics associated with productivity and a residual. This residual is the pure gender effect. According to Harkness (1996) about half of the gap in Britain prior to 1992 was unexplained by differences in individual characteristics rising to some 60\% in 1992. Following the work of Bergmann (1971) and Groshen (1991) a further component of the gap due to segregation of women into particular occupations has been shown to be important. Analogously, segregation at the workplace level may make an important contribution to explaining the gap.

In the huge body of literature on the gender pay gap there are a very few studies exploiting linked evidence on both individual worker characteristics and those of their workplaces (Holzer and Neumark, 2000; Abowd et al, 2001; Bayard et al, 2004) as an additional feature which might explain the earnings gap. Finding the unexplained component of the earnings gap in the US to be higher in smaller workplaces.

In this study, we extend these earlier papers by concentrating on the determination of individual employee's wages given knowledge of the workplace where they are employed and their occupation in addition to their individual characteristics. In particular, we are interested in discovering what happens to the earnings gap and its determination as we vary workplace characteristics. We ask if low wage individuals are concentrated in low wage workplaces. We also want to know whether there are identifiable characteristics of individual employees associated with them being more likely to have 
lower (or higher) pay. An important related issue is that of labour market segregation. We identify the contribution of workplace and occupational segregation to the earnings gap and examine the remaining within-workplace and within-occupation earnings gap.

Having described the data set in section II of the paper, we go on to discuss the determination of earnings at the individual level in section III. Section IV discusses econometric issues and results. In section $\mathrm{V}$ we decompose the gender earnings gap and further explore the impact of segregation. We conclude in section VI.

\section{Data}

The data used in this study are drawn from the British Workplace Employee Relations Survey 1998 (WERS98) ${ }^{1}$. WERS98 is the largest, currently available, survey of its type and was conducted between October 1997 and June 1998.

WERS98 is a nationally representative survey of workplaces with 10 or more employees containing a vast amount of information. Face-to-face interviews for WERS98 were conducted with a manager (with day-to-day responsibility for employee relations) at 2,191 workplaces between October 1997 and June 1998. Furthermore, at each of 1,880 of these workplaces, a questionnaire was presented to 25 randomly selected employees (in workplaces with more than 25 employees) or to all the employees (in workplaces with fewer than 26 employees), resulting in over 28,000 completed employee questionnaires. The response rates were $80 \%$ for the face-to-face management and worker representative interviews and nearly $65 \%$ for the employee questionnaire. WERS98 is a stratified random sample, and larger workplaces and some industries are over-represented. Thus, all of the empirical results that follow use workplace and employee sampling weights. Brief variable definitions and sample statistics are presented in Table 1.

WERS98 and its predecessors have been used to analyze diverse research questions (Millward et al. 2001), but we are not aware of any research using these data to examine the gender earnings gap in Britain. Retaining only those individuals who have complete information for the variables used in the analyses below leaves 25,099 individuals from 1,781 workplaces.

\footnotetext{
${ }^{1}$ Department of Trade and Industry (1999). Workplace Employee Relations Survey: Cross-Section, 1998 (computer file). $4^{\text {th }}$ ed. Colchester: The Data Archive (distributor), 22 December 1999. SN: 3955.
} 
The WERS98 survey, in total, thus collects for the first time in Britain an extensive range of information on both employees and their workplaces. The new linkable employee surveys add a major, and valuable, component to existing studies of British wages: providing for the possibility of separating out individual from workplace effects on wages and the gender earnings gap.

\section{The Determinants of Earnings}

The majority of authors have adopted the human capital model as the theoretical basis for the earnings function (an extensive recent survey is Chiswick, 2003). This approach will also be used in this paper. At the employee level, it is assumed that wages increase with measures of accumulated skills such as education, work experience, and training. A further three categories of variables will be included. These are demographic variables (which may constrain an individual's choice of jobs such as the presence of dependent children, marital status, race, and disability); job characteristics (working part-time; being on a fixed term contract, current job tenure, and union membership); and occupationand workplace-specific effects (we allow the workplace to have an impact on the productivity of individual employees and thus on the earnings function).

There are obvious overlaps between these categories. Nevertheless, in aggregate they provide a more comprehensive list of variables measuring the relative productivity of workers than has previously been considered for Britain. We discuss them in turn below and present variable definitions and mean values for the entire sample (column one), females (column two), and males (column three) in Table 1.

The data have been weighted throughout the paper to allow for the complex survey design (Deaton, 1998) and thus represent the sampling population. We calculate hourly earnings for each employee by dividing their gross (before tax and other deductions) weekly wages by the hours they usually work each week (including any overtime and extra hours). The survey responses for gross weekly wages are banded in the data set, there are 12 bands. We use the midpoints of these bands ${ }^{2}$.

\footnotetext{
${ }^{2}$ In unreported results, we address the possibility that this banding may affect our results. Using interval regression techniques, we find, however, no significant difference with the more general OLS regression results reported in the text.
} 
Usual hours worked is a continuous measure. On this measure, female hourly earnings are on average $26.5 \%$ below male average hourly earnings. This is the gender earnings gap that we analyze in this paper.

Measures of work experience are usually assumed to be positively related to wages via the ability to acquire skills over the time period the employee has spent working. Typically studies do not have data on the history of actual lifetime work experience across firms for individuals. Instead proxies are provided, the most common of which is potential experience: the age of the individual minus years spent in education ${ }^{3}$. WERS98 does not have information on actual experience over working life; potential experience (age minus education and infant years) is instead used.

The other measure commonly used to capture accumulated skills is training. A simple time spent working measure such as potential experience may not adequately capture the acquisition of skills since different firms offer differing quantities of training to differing sets of employees. It may also be that the most able workers are also those with the highest education levels (where ability is a measure of how fast the employee can learn and adapt to new work demands). If so, changes in technology throughout the economy may lead to a greater concentration of training and further increased productivity amongst the well educated. We include a measure of the length of the time the employee spent in employer-provided training in the previous year. We expect this measure of training to be positively related to wages.

The numbers of individuals receiving employer provided training in Britain are substantial at around $60 \%$ of the workforce. Training funded in this way would be predominantly job specific in nature and is typically not associated with substantially higher earnings. If workers are undergoing specific training programs because they are being introduced to new technology, however, this effect may be offset (Chennells and Van Reenen, 1999). If there are imperfections in the labour market leading to wage compression there may also be increased scope for the employer to provide

\footnotetext{
${ }^{3}$ Swaffield (2003), using the British Household Panel Survey (BHPS), argues that allowing for actual rather than potential experience reduced the unexplained component of the wage gap by some $25 \%$.
} 
general training leading to wage rises (Acemoglu and Pischke, 1998).

A positive relationship is similarly expected between wages and education, not only with the years spent in formal education but also with the quality of that education. This positive relationship has been well documented since Mincer's early work (Chiswick, 2003) and has been shown to be surprisingly robust. WERS98 provides information as to the highest level of education the individual has received in six categories. We can see in Table 1 that some $78.7 \%$ of the population did not proceed with formal education beyond a maximum of the end of secondary school and many of the 'others' probably did not progress beyond primary education.

We include job characteristics measuring whether the individual is employed part-time, fixed term, their current job tenure and union membership status. Labour supply theory suggests that working generates disutility for the employee, thus the more hours demanded by the job the higher expected earnings. This prediction needs to be tempered, however, by the constraints part-time contracts put on the labour supply choices of individuals.

Current job tenure is expected to be positively related to wages primarily because it reflects a successful match between employee and employer. Returns to current job length have often been found to be very small and the major action with this variable in the literature appears to be capturing the wage gains associated with changing jobs (Manning and Robinson, 2004).

Union membership has declined dramatically in Britain since the 1970s; however, in 1998 it was still comparatively high at $39.4 \%$ representing a potentially major source of bargaining power. We also expect the union provides a voice mechanism for the individual thereby leading to less quits, longer tenure and higher wages (Freeman and Medoff, 1984). Unions may also, however, provide a range of other services to their members, which could increase relative job satisfaction and lower the wage rate. Nevertheless, we expect a positive relationship between union membership and the wage.

Finally, the demographic information in WERS98 reveals that the female workforce has fewer dependent children and less disabled members. Females are more likely to be non-white. They also 
have less potential experience, recent training, and current job tenure. They are substantially more likely to be on a fixed term contract and are four times more likely to work part time than are men.

\section{Estimating the Earnings function}

Using semi-logarithmic wage equations, we estimate the earnings equation as:

$$
W_{i}=\alpha+X_{i} \beta+G_{i} X_{i} \gamma+\varepsilon_{i}
$$

where $W_{i}$ is the natural $\log$ of the wage for individual $i ; \alpha$ is an intercept term; $X_{i}$ is a vector of regressors capturing the individual characteristics expected to impact on wages; and $\varepsilon_{i}$ is a residual term. An indicator variable $G$ identifies females in the dataset and the coefficients $\gamma$ measure where the coefficients on any of the variables $X_{i}$ differ between men and women. We thus base our analysis on pooled wage equations for men and women rather than on separate estimates for the two groups (Neumark, 1988). We call this model A and estimate it using ordinary least squares.

The linked nature of WERS98 can be used to good effect to incorporate workplace information into the analysis of individual wages. Typically individual-based data sets, whilst they may include some broad workplace information, cannot identify where more than one individual in the data is employed in any given workplace. We can allow for workplace specific fixed effects where the model to be estimated is:

$$
W_{i}=\alpha_{k}+X_{i k} \beta+G_{i} X_{i k} \gamma+\varepsilon_{i k}
$$

where $k$ represents the workplace and $\alpha_{k}$ the workplace specific effect. Workplace specific effects and individual characteristics are not assumed to be uncorrelated and it is possible to recover the proportional contributions of the two types of effect. We expect both types of effect to be important.

The workplace specific effect $\alpha_{k}$ also captures unobservable individual effects common to all employees in a workplace. It is not possible to identify the remaining idiosyncratic effects and we relegate them to the residual. This will have no consequence for the estimate of $\alpha_{k}$ if the remaining individual effects are uncorrelated with these included workplace specific effects.

Individual specific effects for unobservable individual characteristics are often included to 
capture constant differences across individuals (such as may be generated by differences in their family backgrounds), however, the validity of their use to capture potentially very important differences in ability and motivation is not so obvious. For example, it is often assumed that ability is either acquired (via education and training) or innate. This separability is not obvious: ability and training may not only complementary, the functional relationship between them could be multiplicative whereby training increases ability. Similarly, it is not obvious that motivation levels for the individual are constant over time. It is already well recognised that age affects motivation but so might the presence of small children, alienation with current work environment, the availability of outside job offers, etc. We believe that our estimates will not be affected seriously by our approach (Mumford and Smith, 2004) especially given the array of explanatory variables that we do include, a point we elaborate on further in discussing the results below.

In evaluating the estimation results we will measure the relative explanatory contribution of individual characteristics and workplace specific effects by comparing Models A and B. An issue that we can address by this comparison is that of segregation. For example, if a demographic identifier is significant in the OLS estimates but not in the fixed effect estimates, then we can attribute the impact of membership of that demographic group to the workplace rather than to the worker's individual characteristic. This could be evidence suggesting workplace segregation.

We can also measure the impact of segregation in a more direct way. Segregation results in disproportionate concentration of employees with a given characteristic, in this case being female. It can occur at many levels in the work environment, those levels most commonly considered are the occupation and workplace (Altonji and Blank, 1999; Groshen, 1991; Bayard et al, 2004). We would expect segregation to impact negatively on the female wage if it leads to overcrowding and thereby lower marginal productivity (Bergmann, 1971).

Groshen (1991) using US data found that the majority of the gender earnings gap could be attributed to occupational segregation. She also found that men and women rarely carry out the same jobs within an establishment, however, when they do their wages are similar. Segregation at the establishment level only accounted for some $6 \%$ of the gap and the major relationship between the earnings gap and segregation occurs at the occupational level, capturing one-half to two-thirds of the 
gap. She concluded that there was a need for job evaluation systems based on comparable-worth principles in order to lower the gap.

Bayard et al (2004) re-examine Groshen's work and find results contradicting Groshen. Using a broader range of data, which includes more industries and occupations, they find that the majority of the earnings gap is due to the individual's gender and not explained by segregation. According to their results, segregation within occupations at the establishment level is associated with a substantial proportion of the gap (one-quarter to one-half) but this is much smaller than Groshen found. Bayard et al (2004) consequently advocate stronger enforcement of equal pay acts to reduce the gender pay gap.

The WERS98 data set, uniquely for Britain, allows us to examine in detail the possible importance of segregation in occupations and workplaces. In common with Bayard et al (2004) we estimate the following wage regression,

$$
W_{i}=\alpha+X_{i} \beta+G_{i} X_{i} \gamma+\delta^{l} \% F_{i}^{l}+\varepsilon_{i}
$$

where $l=k, o$, and $l$ is the structural level (workplace $k$, or occupation $o$ ); $\% \mathrm{~F}$ is the percent female in the level indicated by the superscript. We present results considering the inclusion of the segregation measure only at the occupational level $(l=o)$ which we call Model $\mathrm{C}$; and segregation at both the workplace and occupational levels $(l=k, o)$ which we call Model D.

\section{A. Results for the Earnings Function}

The estimates of the four earnings equations we estimate for individual workers (Models A, B, $\mathrm{C}$ and D) are given in Table 2. Beginning with Model A in column one, the traditional human capital measures show a strongly significant, positive impact of educational achievement on earnings. The return to a degree relative to completing secondary school (A levels) is $32 \%$. Earnings are a further $16 \%$ higher for postgraduates. Potential worker experience also has a strongly significant positive effect, although decreasing in size at higher ages. Five years more work experience is associated with $16.5 \%$ higher wages according to our results.

Demographic effects on earnings are also found to be important in these results. Female, ethnic 
and disabled groups are all paid less. The simple intercept dummy variable effects are $7.2 \%$ for the disabled and $8.9 \%$ for the ethnic group. In addition, those who are married with dependent children have higher earnings according to our results.

Our final set of variables relates to job characteristics. Current job tenure has a significant and positive impact on earnings. At the average uncompleted tenure of 5.3 years, earnings are $6 \%$ higher than those for a new worker. Likewise those working full time and not on fixed term contracts can be expected to earn more on an hourly basis. Finally, the earnings premium associated with union membership is estimated to be $9.2 \%$.

Most of the coefficients described above are reduced in size and often in significance once the impact of a workplace specific effect is allowed for (Model B in column 2). This suggests some interaction between workers of a given characteristic and the workplace in which they work - which we explore further below.

Models $\mathrm{C}$ and $\mathrm{D}$ introduce our direct measures of segregation: Model $\mathrm{C}$ considers only occupational segregation whilst Model D (our preferred model) also includes potential workplace segregation. We find both forms of segregation are associated with a lower wage rate, more so with workplace segregation.

\section{B. Analysis of Variance}

The relative contributions of individual characteristics and workplace specific effects on the behaviour of wages, and the relationship between them, can be explored in more detail with the analysis of variance for Model B presented in Table 3. The overall fit of $63.9 \%$ can be broken down into the fit due solely to the individual variables of $47.3 \%$ and that of the workplace specific fixed effects of $44.7 \%$. These influences on individual wages therefore are of rather similar importance; $19.2 \%$ in the case of individual effects and $16.5 \%$ for workplace specific effects on the margin.

The results further show that wage variation within and across workplaces is strongly influenced by observed individual characteristics. One way of judging how large the impact of different 
characteristics on wages could be is to examine the standard deviations of the two types of influences. A workplace paying wages one standard deviation above the mean, conditional on individual characteristics, pays a substantial premium of $29.7 \%$ according to our results. Furthermore, the two sets of influences are related with a correlation coefficient of 0.446 .

These results imply that those employees with individual and job characteristics, which generate higher wages, tend to work in workplaces that also pay higher wages. It is still the case, however, that a gap exists between the pay of men and women, ceteris paribus. In the next section we examine the decomposition of this pay gap.

\section{Decomposing the Gender Pay Gap}

We find an earnings gap between men and women of 0.265 , or $26.5 \%$. The approach we adopt to apportion the gap in the mean earnings of men and women is that proposed by Neumark (1988) and discussed further in Oaxaca and Ransom (1994) where the reference set of parameters is given by the pooled estimates presented in Table 2 .

$$
\bar{W}_{m}-\bar{W}_{f}=\left(\bar{X}_{m}-\bar{X}_{f}\right) \hat{\beta}-\bar{X}_{f} \hat{\gamma}+\hat{\delta}^{k}\left(\% \bar{F}_{m}^{k}-\% \bar{F}_{f}^{k}\right)+\hat{\delta}^{o}\left(\% \bar{F}_{m}^{o}-\% \bar{F}_{f}^{o}\right)
$$

The decompositions of the earnings gap for Models A, B, C and D are presented in Table 4.

Beginning with Model A in panel one, the results show a fairly even split of the $26.5 \%$ average earnings gap between the two alternative sources. Thus, of the earnings gap $30.9 \%$ is due to the genders having different individual characteristics and the remaining $69.1 \%$ due to the gender effect. ${ }^{4}$ Introducing workplace specific effects in Model B changes the relative contribution of these two effects to $50.7 \%$ and $49.3 \%$ respectively. Therefore our results suggest that allowing for workplace specific

\footnotetext{
${ }^{4}$ Harkness (1996) finds an all males and full-time females earnings gap for the 1992/1993 British Household Panel Survey (BHPS) data of $22.1 \%$ and, using the female wage as the non-discriminatory base line, also apportions $92 \%$ to discrimination and $8 \%$ to productivity differences. She finds a rather larger earnings gap between all males and part-time females of which a rather larger amount (66\%) is due to productivity differences. Thus overall, our measure of the earnings gap is probably somewhat lower than that of Harkness with less due to productivity differences.
} 
effects increases the relative impact of individual characteristics.

Considering Model C and Model D, we find the explicit introduction of segregation effects in our analysis to be important, especially so for workplace segregation which accounts for $29 \%$ of the gender earnings gap. The pure gender effect falls in Model D, however, it is still substantial at $42 \%$ of the earnings gap (or a difference of $11.3 \%$ in wages).

An important part of our estimates of the role of workplace fixed effects is the finding of a positive correlation between workers wages and workplace average wages. The lower part of Table 4 presents results of decompositions that analyse the earnings gap in workplaces in the two ends of the wage distribution.

We analyse the earnings gap for workers in low pay workplaces, with average wages less than half of one standard deviation below mean workplace wages. We also examine workers in workplaces that pay, on average, more than half of one standard deviation above the mean. Low pay workplaces contain $16 \%$ of workers, whilst high pay workplaces contain $51 \%$, reflecting their greater size and some further skewness in the wage distribution. The earnings gap in the low pay workplaces is only $7.3 \%$, a quarter of that for the full sample. The earnings gap in high pay workplaces is some $22 \%$, a little below the mean.

In estimating the wage equation for workers in these workplaces we control for the selection of workers into either low or high wage workplaces by using the traditional Heckman method of including the inverse Mills ratio. We estimate this model using Maximum Likelihood. The selection term is significant for both high and low wage workplaces. In the estimation of the selection equation we include the local area vacancy rate and industry dummy variables as additional variables. These improve identification of the selection effect. Despite the lower earnings gap, the breakdown of the earnings gap for the simultaneously estimated low wage workplaces shows a pure gender effect of $13 \%$ which is in line with the results for the full sample. This is offset in accounting for the earnings gap by significant negative contributions from differences in individual characteristics and workplace segregation. The difference in individual characteristics between low pay and average workplaces is that in this sector men are younger with shorter current tenure and fewer are married. The advantages of better education, more training, and higher unionisation are also absent for men in these workplaces, which keeps down their relative wage. 
In high wage workplaces women are similarly better educated which contributes to a negligible effect on the earnings gap from individual characteristics in this sector. Again the pure gender effect is large and, in this case, somewhat greater than for the average workplace. The remaining major difference is that occupational segregation makes a much larger contribution to the earnings gap whilst that of workplaces in small.

Selection to low or high workplaces itself explains only a small part of the earnings gap. It is larger and more positive in low than in high wage workplaces suggesting that these women may be less mobile geographically. In Table 5 we present the breakdown of the earnings gap for a number of geographical regions and industrial sectors where these are substantially different from the full sample results using our preferred model (Model D). We re-estimate the earnings model for each of these regions and sectors. The earnings gap is much larger in the North East of England and smaller in London. According to our results the former is due to much larger workplace segregation and pure gender effects than in Britain as a whole. In the case of London these two effects are much smaller than average. Workplace segregation is more important in Scotland and much less so in Wales where differences in characteristics explain more than $45 \%$ of the earnings gap. The earnings gap in Manufacturing is substantially higher than across all sectors and much lower in the health sector. In both Manufacturing and Public Administration the pure gender effect is over 50\% of the earnings gap. In Health a low workplace segregation effect and a much lower than average pure gender effect of less than $5 \%$ or a quarter of the earnings gap is offset to some extent by large differences in characteristics. Finally, we examine workers in workplaces with an active Equal Opportunities policy in place. The pure gender effect is lower for these workers although the earnings gap is slightly higher. The remaining difference being due to higher workplace and occupational segregation.

The results of the decompositions for both the aggregate labour market and sub-sectors suggest a role for comparable worth pay policy where occupational segregation is found to be a significant component of the earnings gap. The most important policy response, however, would be more effective application of equal pay legislation. We find a substantial within-workplace, within-occupation earnings gap which should be amenable to such a policy response. An example of such a policy (in the extreme) which was implemented soon after the data for this study was collected is the Minimum Wage legislation introduced in April 1999. For our purposes this can be regarded as binding equal pay legislation for the lowest paid. 
We experiment by applying the Minimum Wage to our hourly pay data and recalculating the earnings gap. Following the suggestion of Forth and Millward (2001), we impose a minimum hourly pay for those over 21 in our sample at $£ 3.50$ /hour and $£ 2.92$ for those aged less than 22 . These rates are the announced levels for April 1999 of $£ 3.60$ and $£ 3.00$ deflated for wage inflation between the date of the WERS survey and April 1999.

According to this calculation, the impact of the introduction of the Minimum Wage has an overall effect of reducing the earnings gap substantially from $26.5 \%$ to $23.4 \%$ or 3.1 percentage points. The effect is not, however, uniform across all sectors. Of the sub-sectors of the dataset represented in Tables 4 and $5^{5}$, the largest impact of the Minimum Wage is on the earnings gap in the North East, reducing it by about a fifth or 7.0 percentage points. In other lower wage sectors it also has a large impact, 6.1 percentage points in Wales and a proportionally similar 1.6 percentage points in Low Wage workplaces. All of these sectors have an above-average pure gender effect in the original data. The impact in the lower than average pay Health sector is, however, small and similar to high wage sectors like Public Administration and London. In these sectors relatively few workers are paid below the minimum wage level and these workers are not disproportionately female.

Our cross sector analyses suggests a need for general policies, providing both equal pay and comparable worth, which are capable of being targeted to sectors and occupations.

\section{Conclusion.}

This paper analyses the determination of individuals wages in Britain employing a linked data set of employees and their workplaces (WERS98). We show that the addition of workplace specific effects in a standard human capital based earnings function adds an important feature to our understanding of the determination of wages. Workplace specific effects explain as much of the variation of gross hourly pay as do individual worker and job characteristics. With the estimates we show that workers with good characteristics who are paid more tend to work in workplaces that pay

\footnotetext{
${ }^{5}$ The wage gaps after imposing the Minimum Wage are: Full Sample 0.234, Low Wage 0.057, High Wage 0.216, Wales 0.193, Scotland 0.223, London 0.190, North East 0.291, Manufacturing 0.308, Public Admin 0.256, Health 0.157, EO 0.252
} 
more. There remains, however, a substantial disparity between the average level of pay for men and women across all workplaces.

We find a gender earnings gap for Britain of $26.5 \%$. This earnings gap is not uniform but it is substantial across sectors of the workforce, varying between 7.3\% in Low Wage workplaces to 36\% in workplaces located in the North-East. Some quarter of the overall gender earnings gap can be explained by women having individual characteristics associated with lower earnings; although it is as high as $58 \%$ in the Health sector and as low as $12 \%$ in Public Administration.

Workplace segregation is found to have a significant and substantial impact, especially in Scotland and the North East where physical distances may limit the employment opportunities for women. This finding suggests a need to strengthen the current equal pay provisions to ensure acrossworkplace comparability and pay equity. The implementation of Equal Opportunity policies in workplaces does not appear to reduce the effect of workplace segregation. Rather, its positive relationship with the pay gap is actually higher in workplaces with such a policy in place.

Our results suggest that the introduction of Minimum Wage legislation will have reduced the gender earnings gap but far from removed it, as we would expect, given it's limited operation at the bottom end of the wage distribution only.

Whilst we do not find consistently sizeable impacts from occupational segregation on the gender earnings gap, it is an important factor in both High and Low wage workplaces. This suggests a role for comparable worth pay legislation in lowering the gap in some workplaces. Nevertheless, the major component of the earnings gap between men and women in Britain is associated with the gender effect. We have demonstrated that this is a within-occupation, within-workplace effect This finding suggests that the Equal Pay legislation in Britain is not fully effective. 


\section{References}

Abowd, J.M., F. Kramarz, D.N. Margolis, D.N., and Troske, K. 2001. “The Relative Importance of Employer and Employee Effects on Compensation: A Comparison of France and the United States." Journal of the Japanese and International Economies 15(4): 419-436.

Acemoglu, D. and Pischke, J.S. 1998. "Why do Firms Train? Theory and Evidence." Quarterly Journal of Economics 113(1): 79-119.

Altonji, J.G. and Blank, R. 1999. "Race and Gender in the Labor Market" in Ashenfelter, O. and Card, D. (eds.) Handbook of Labor Economics. Elsevier Science B.V, Amsterdam.

Bayard, K., Hellerstein, J., Neumark. D. and Troske, K. 2004. "New Evidence of Sex Segregation and Sex Differences in Wages from Matched Employee-Employer Data.” Forthcoming in the Journal of Labor Economics.

Bergmann, B.R. 1971. “Occupational Segregation, Wages and Profits when Employers Discriminate by Race or Sex”. Eastern Economic Journal. 1:103-110.

Blau, F.D. and Kahn, L.M. 1997. "Swimming Upstream: Trends in the Gender Wage Gap Differential in the 1980s." Journal of Labor Economics 15(1): 1-42.

Chennels, L. and Van Reenen, J. 1999. "Has Technology Hurt Less Skilled Workers? An Econometric Survey of the Effects of Technical Change on the Structure of Pay and Jobs." Institute for Fiscal Studies Working Paper 99/27.

Chiswick, B.R. 2003. "Jacob Mincer, Experience and the Distribution of Earnings.” IZA Discussion Paper No. 847, Bonn.

Deaton, A. 1998. The Analysis of Household Surveys. A Microeconometric Approach to Development Policy. World Bank. John Hopkins University Press, Baltimore.

Department of Trade and Industry (1999) Workplace Employee Relations Survey: Cross-Section, 1998 (computer file). $4^{\text {th }}$ ed. Colchester: The Data Archive (distributor), 22 December 1999. SN: 3955 .

Forth, J. and Millward, N. 2001. "The Low Paid-Worker and the Low-Paying Employer: Characterisations using WERS98.” NIESR Discussion Paper 179.

Freeman, R., and J. Medoff. 1984. What Do Unions Do? Basic Books, New York.

Groshen, E. 1991. "The Structure of The Female/Male Wage Differential. Is It Who You Are, What You Do, or Where You Work?” Journal of Human Resources 26(3): 457-472.

Harkness, S. 1996. “The Gender Earnings Gap: Evidence from the UK.” Fiscal Studies 17: 1-36.

Holzer, H. and Neumark, D. 2000. “Assessing Affirmative Action.” Journal of Economic Literature 38: 483-568. 
Joshi, H., and P. Paci, 1998. Unequal Pay for Men and Women. MIT Press, Cambridge Massachusetts. Manning, A. and Robinson, H. 2004. "Something in the Way She Moves: A Fresh Look at an Old Gap.” Forthcoming in Oxford Economic Papers.

Millward, N., Woodland, S., Bryson, A., Forth, J., and Simon Kirby. 2001. "A Bibliography of Research Based on the British Workplace Industrial Relations Survey Series.” London: National Institute for Economic and Social Research. Retrieved October 8, 2001, from http://www.niesr.ac.uk/niesr/wers98/Bib2001.pdf.

Mumford, K. and Smith, P.N. 2004, "Job Tenure in Britain: Employee Characteristics versus Workplace Effects." Forthcoming in Economica.

Neumark, D. 1988. "Employer's Discriminatory Behaviour and the Estimation of Wage Discrimination." Journal of Human Resources 23(3): 279-295.

Oaxaca, R.L., and Ransom, M.R. 1994. "On Discrimination and the Decomposition of Wage Differentials." Journal of Econometrics 61: 5-24.

Swaffield, J.K. 2003. "Gender, Motivation, Experience and Wages." Mimeo, Department of Economics, University of York.

Weichselbaumer, D., and Winter-Ebmer, R., 2003. “A Meta-Analysis of the International Gender Wage Gap." IZA Discussion Paper 906, October.

Wilborn, S.L. 1991. "Economic and Legal Perspectives on Women's Wages in Six Countries: An Overview." in S.L. Wilborn, ed. Women's Wages: Stability and Change in Six Industrial Countries. Greenwich, CN: JAI Press. 
Table 1. Variable definitions and means.

\begin{tabular}{|c|c|c|c|}
\hline \multirow[b]{2}{*}{ Variable definitions } & \multicolumn{3}{|c|}{ Mean values } \\
\hline & All & Female & Male \\
\hline Hourly pay & 7.319 & 6.274 & 8.320 \\
\hline Log hourly pay & 1.814 & 1.679 & 1.944 \\
\hline Potential experience & 23.566 & 23.392 & 23.733 \\
\hline Length of training in previous year & 2.476 & 2.309 & 2.636 \\
\hline Other education level & 0.250 & 0.241 & 0.259 \\
\hline CSE or equivalent & 0.122 & 0.113 & 0.130 \\
\hline O level or equivalent & 0.266 & 0.297 & 0.236 \\
\hline A level or equivalent & 0.149 & 0.149 & 0.149 \\
\hline Degree or equivalent & 0.158 & 0.150 & 0.165 \\
\hline Postgraduate degree or equivalent & 0.055 & 0.049 & 0.062 \\
\hline Any dependent children aged $0-18$ & 0.417 & 0.398 & 0.434 \\
\hline Living with spouse or partner & 0.695 & 0.694 & 0.697 \\
\hline On-going physical disability & 0.060 & 0.053 & 0.068 \\
\hline Non-white ethnic group & 0.038 & 0.040 & 0.035 \\
\hline Fixed term contract & 0.032 & 0.036 & 0.027 \\
\hline Part time employment & 0.291 & 0.485 & 0.105 \\
\hline Current job tenure & 5.324 & 5.046 & 5.591 \\
\hline Trade union member & 0.394 & 0.333 & 0.453 \\
\hline Managers and senior administrators & 0.087 & 0.057 & 0.117 \\
\hline Professionals & 0.131 & 0.119 & 0.142 \\
\hline Associate professional and technical & 0.091 & 0.099 & 0.082 \\
\hline Clerical and secretarial & 0.161 & 0.267 & 0.060 \\
\hline Craft and skilled service & 0.104 & 0.033 & 0.173 \\
\hline Personal and protective services & 0.080 & 0.091 & 0.070 \\
\hline Sales operator, sales assistant & 0.096 & 0.139 & 0.054 \\
\hline Operative and assembly & 0.129 & 0.063 & 0.192 \\
\hline Other occupational group & 0.121 & 0.132 & 0.110 \\
\hline Female & 0.489 & 1.000 & 0.000 \\
\hline Proportion of females in workplace & 49.791 & 68.065 & 32.283 \\
\hline Proportion of females in occupation & 48.197 & 57.492 & 39.291 \\
\hline Sample size & 25099 & 12615 & 12484 \\
\hline
\end{tabular}

Source: Workplace Employee Relations Survey: Cross-Section, 1998 (computer file). $4^{\text {th }}$ ed. Colchester: The Data Archive (distributor), 22 December 1999. SN: 3955. (WERS98). The sample means are fully weighted to account for the complex survey design. 
Table 2. Earnings functions

\begin{tabular}{|c|c|c|c|c|}
\hline & $\frac{\text { Model A }}{\text { OLS }}$ & $\frac{\text { Model B }}{\mathrm{FE}}$ & $\frac{\text { Model C }}{\text { OLS }}$ & $\frac{\text { Model D }}{\text { OLS }}$ \\
\hline Potential experience & $\begin{array}{r}0.038 \\
(13.33)\end{array}$ & $\begin{array}{r}0.027 \\
(12.07)\end{array}$ & $\begin{array}{r}0.037 \\
(13.24)\end{array}$ & $\begin{array}{r}0.037 \\
(13.33)\end{array}$ \\
\hline Potential experience squared & $\begin{array}{r}-0.001 \\
(-10.66)\end{array}$ & $\begin{array}{r}0.000 \\
(-10.30)\end{array}$ & $\begin{array}{r}-0.001 \\
(-10.59)\end{array}$ & $\begin{array}{r}-0.001 \\
(-10.75)\end{array}$ \\
\hline Training in previous 12 months & $\begin{array}{l}0.015 \\
(9.77)\end{array}$ & $\begin{array}{l}0.002 \\
(1.93)\end{array}$ & $\begin{array}{l}0.015 \\
(9.89)\end{array}$ & $\begin{array}{r}0.016 \\
(10.39)\end{array}$ \\
\hline \multicolumn{5}{|l|}{$\begin{array}{l}\text { Education (ommitted category is A level } \\
\text { or equivalent) }\end{array}$} \\
\hline Other education level & $\begin{array}{r}-0.346 \\
(-19.93)\end{array}$ & $\begin{array}{l}-0.123 \\
(-8.29)\end{array}$ & $\begin{array}{r}-0.354 \\
(-21.37)\end{array}$ & $\begin{array}{r}-0.361 \\
(-22.77)\end{array}$ \\
\hline CSE or equivalent & $\begin{array}{r}-0.258 \\
(-14.71)\end{array}$ & $\begin{array}{l}-0.097 \\
(-6.80)\end{array}$ & $\begin{array}{r}-0.264 \\
(-15.81)\end{array}$ & $\begin{array}{r}-0.271 \\
(-16.75)\end{array}$ \\
\hline O level or equivalent & $\begin{array}{r}-0.137 \\
(-10.85)\end{array}$ & $\begin{array}{l}-0.059 \\
(-5.94)\end{array}$ & $\begin{array}{r}-0.138 \\
(-11.18)\end{array}$ & $\begin{array}{r}-0.144 \\
(-12.12)\end{array}$ \\
\hline Degree or equivalent & $\begin{array}{r}0.316 \\
(20.99)\end{array}$ & $\begin{array}{l}0.124 \\
(9.11)\end{array}$ & $\begin{array}{r}0.312 \\
(20.78)\end{array}$ & $\begin{array}{r}0.324 \\
(21.38)\end{array}$ \\
\hline Postgraduate degree or equivalent & $\begin{array}{r}0.483 \\
(20.05)\end{array}$ & $\begin{array}{l}0.210 \\
(8.39)\end{array}$ & $\begin{array}{r}0.478 \\
(19.74)\end{array}$ & $\begin{array}{r}0.503 \\
(20.97)\end{array}$ \\
\hline Dependent child aged 0-18 & $\begin{array}{l}0.033 \\
(2.14)\end{array}$ & $\begin{array}{l}0.027 \\
(2.44)\end{array}$ & $\begin{array}{l}0.032 \\
(2.06)\end{array}$ & $\begin{array}{l}0.030 \\
(1.92)\end{array}$ \\
\hline Living with spouse or partner & $\begin{array}{l}0.155 \\
(9.48)\end{array}$ & $\begin{array}{l}0.071 \\
(6.49)\end{array}$ & $\begin{array}{l}0.154 \\
(9.60)\end{array}$ & $\begin{array}{l}0.147 \\
(9.62)\end{array}$ \\
\hline On-going physical disability & $\begin{array}{l}-0.072 \\
(-3.65)\end{array}$ & $\begin{array}{l}-0.052 \\
(-3.19)\end{array}$ & $\begin{array}{l}-0.072 \\
(-3.65)\end{array}$ & $\begin{array}{l}-0.070 \\
(-3.55)\end{array}$ \\
\hline Non-white ethnic group & $\begin{array}{l}-0.089 \\
(-2.22)\end{array}$ & $\begin{array}{l}-0.089 \\
(-2.49)\end{array}$ & $\begin{array}{l}-0.086 \\
(-2.16)\end{array}$ & $\begin{array}{l}-0.084 \\
(-2.08)\end{array}$ \\
\hline Fixed term contract & $\begin{array}{l}-0.057 \\
(-1.97)\end{array}$ & $\begin{array}{l}-0.078 \\
(-2.84)\end{array}$ & $\begin{array}{l}-0.057 \\
(-1.99)\end{array}$ & $\begin{array}{l}-0.056 \\
(-1.97)\end{array}$ \\
\hline Part time employment & $\begin{array}{l}-0.112 \\
(-6.66)\end{array}$ & $\begin{array}{l}0.100 \\
(5.45)\end{array}$ & $\begin{array}{l}-0.108 \\
(-6.25)\end{array}$ & $\begin{array}{l}-0.076 \\
(-3.93)\end{array}$ \\
\hline Current job tenure & $\begin{array}{r}0.017 \\
(12.24)\end{array}$ & $\begin{array}{l}0.010 \\
(8.71)\end{array}$ & $\begin{array}{r}0.017 \\
(12.16)\end{array}$ & $\begin{array}{r}0.017 \\
(11.80)\end{array}$ \\
\hline Trade union member & $\begin{array}{l}0.092 \\
(5.38)\end{array}$ & $\begin{array}{l}0.058 \\
(5.56)\end{array}$ & $\begin{array}{l}0.090 \\
(5.44)\end{array}$ & $\begin{array}{l}0.086 \\
(5.54)\end{array}$ \\
\hline \multicolumn{5}{|l|}{ Interactive measures } \\
\hline Female*Potential experience & $\begin{array}{l}-0.005 \\
(-1.63)\end{array}$ & $\begin{array}{l}-0.008 \\
(-2.90)\end{array}$ & $\begin{array}{l}-0.005 \\
(-1.60)\end{array}$ & $\begin{array}{l}-0.005 \\
(-1.46)\end{array}$ \\
\hline Female*Potential experience squared & $\begin{array}{l}0.000 \\
(0.29)\end{array}$ & $\begin{array}{l}0.000 \\
(1.41)\end{array}$ & $\begin{array}{l}0.000 \\
(0.29)\end{array}$ & $\begin{array}{l}0.000 \\
(0.29)\end{array}$ \\
\hline Female*Dependent children aged 0-18 & $\begin{array}{l}-0.070 \\
(-3.48)\end{array}$ & $\begin{array}{l}-0.062 \\
-3.71)\end{array}$ & $\begin{array}{l}-0.069 \\
(-3.42)\end{array}$ & $\begin{array}{l}-0.063 \\
(-3.17)\end{array}$ \\
\hline Female*Living with spouse or partner & $\begin{array}{l}-0.103 \\
(-4.80)\end{array}$ & $\begin{array}{l}-0.037 \\
(-2.31)\end{array}$ & $\begin{array}{l}-0.101 \\
(-4.78)\end{array}$ & $\begin{array}{l}-0.095 \\
(-4.66)\end{array}$ \\
\hline Female*Non-white ethnic group & $\begin{array}{l}0.116 \\
(2.43)\end{array}$ & $\begin{array}{l}0.037 \\
(0.89)\end{array}$ & $\begin{array}{l}0.112 \\
(2.36)\end{array}$ & $\begin{array}{l}0.109 \\
(2.25)\end{array}$ \\
\hline
\end{tabular}




\begin{tabular}{|c|c|c|c|c|}
\hline & $\frac{\text { Model A }}{\text { OLS }}$ & $\frac{\text { Model B }}{\mathrm{FE}}$ & $\frac{\text { Model C }}{\text { OLS }}$ & $\frac{\text { Model D }}{\text { OLS }}$ \\
\hline Female & $\begin{array}{l}0.019 \\
(0.63)\end{array}$ & $\begin{array}{l}0.056 \\
(1.85)\end{array}$ & $\begin{array}{l}0.026 \\
(0.84)\end{array}$ & $\begin{array}{l}0.068 \\
(2.29)\end{array}$ \\
\hline Proportion of females in workplace & $\ldots$ & $\ldots$ & $\ldots$ & $\begin{array}{l}-0.002 \\
(-6.27)\end{array}$ \\
\hline Proportion of females in occupation & $\ldots$ & $\ldots$ & $\begin{array}{l}-0.001 \\
(-2.08)\end{array}$ & $\begin{array}{r}-0.0004 \\
(-1.38)\end{array}$ \\
\hline Occupation controls & $\ldots$ & Yes & $\ldots$ & \\
\hline constant & $\begin{array}{r}1.278 \\
(42.09)\end{array}$ & $\begin{array}{r}1.344 \\
(46.96)\end{array}$ & $\begin{array}{r}1.313 \\
(37.89)\end{array}$ & $\begin{array}{r}1.382 \\
(36.25)\end{array}$ \\
\hline $\begin{array}{l}\text { Sample size } \\
\text { Adjusted R squared } \\
\text { F test joint significance }\end{array}$ & $\begin{array}{r}25099 \\
0.387 \\
268.53 \\
F(22,1690) \\
\end{array}$ & $\begin{array}{r}25099 \\
0.611 \\
161.99 \\
F(29,23288) \\
\end{array}$ & $\begin{array}{r}25099 \\
0.388 \\
257.2 \\
F(23,1689) \\
\end{array}$ & $\begin{array}{r}25099 \\
0.395 \\
254.87 \\
\mathrm{~F}(24,1688) \\
\end{array}$ \\
\hline
\end{tabular}

Source: WERS98. Data are fully weighted to allow for complex survey design. 
Table 3. Variance decomposition

\section{Fraction of variance explained}

individual characteristics and workplace fixed effects

individual characteristics (number)

workplace specific effects (number)

$0.447 \quad(1781)$

Marginal fraction of variance explained

individual characteristics

workplace specific effects

0.165

\section{Standard deviations}

individual characteristics

across workers

workplace specific effects

\section{Correlations}

individual characteristics across workplaces

0.436

Source: WERS98. Data are fully weighted to allow for complex survey design. 


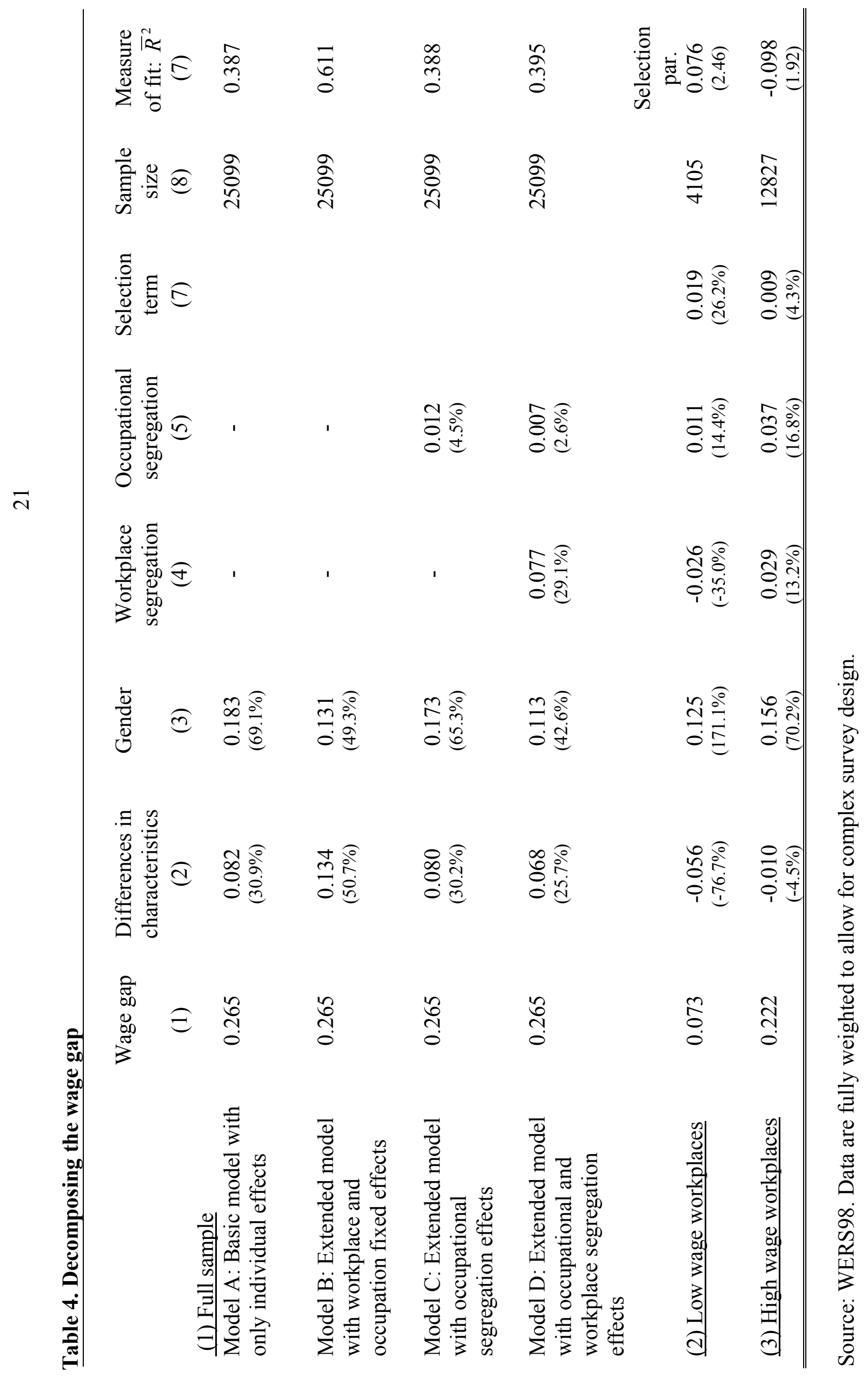




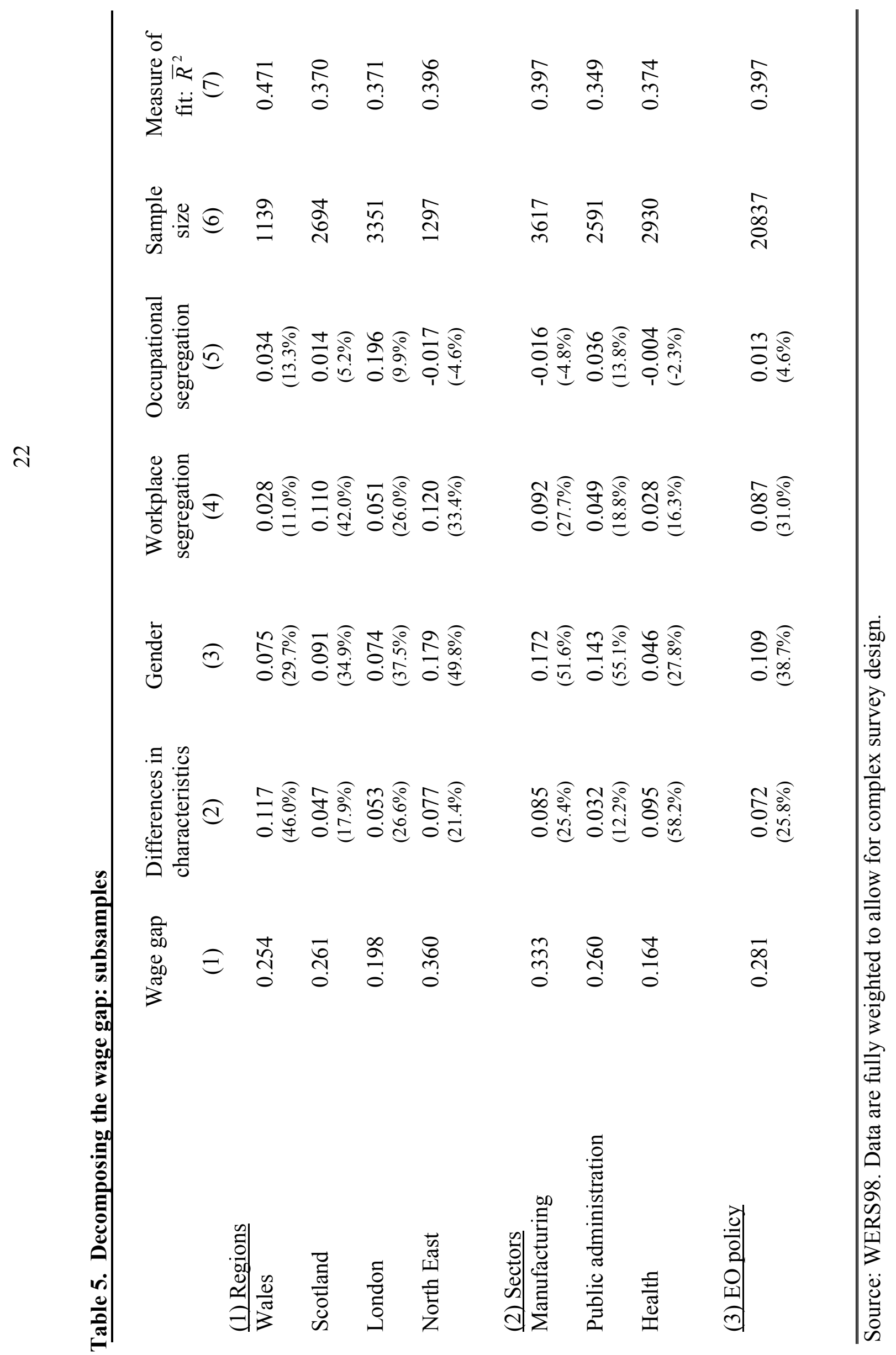

